\title{
ANALISIS REAKSI PASAR BURSA EFEK INDONESIA SEBELUM \\ DAN SESUDAH PENGUMUMAN RIGHT ISSUE TERHADAP ABNORMAL RETURN DAN LIKUIDITAS SAHAM \\ (Studi Kasus Pada Perusahaan-Perusahan Yang Terdaftar Di Bursa Efek Indonesia Tahun 2015-2018 Sektor Infrastruktur)
}

\author{
Yehova Rafa Wajin \\ University of 17 Agustus 1945 Samarinda \\ Jl. Ir. H. Juanda No. 80, 75124, Indonesia \\ yehova19@gmail.com
}

\begin{abstract}
Go public companies in order to increase funds, companies can conduct corporate actions, namely rights issues. Right issue is a new share offering from the company for old investors with a system offering it to an old investor first. The information about the rights issue was published as an announcement that could be used to see market reactions. This market reaction is measured by abnormal returns to see stock returns and trading volume activity to see stock liquidity.

This research intend to see abnormal stock returns and stock liquidity before and after the announcement of the rights issue with a sample of infrastructure sector companies in the Indonesia Stock Exchange for the period 2015-2018 with purposive sampling technique of sample selection, according to predetermined criteria then obtained 6 companies.

This research is a descriptive study using quantitative methods. The test used in this study is the normality test then using a paired sample t-test. The results of this study show no significant difference from abnormal returns and stock liquidity before and after the announcement of the rights issue.
\end{abstract}

\section{Keywords: Market Reaction, Corporate Action, Abnormal Return, Right Issue}

\section{PENDAHULUAN}

Perkembangan ekonomi yang terjadi di suatu negara seiring dengan adanya perkembangan jaman maka persaingan semakin ketat yang akhirnya memberikan alternatif kepada masyarakat untuk melakukan investasi. Investasi merupakan komitmen pendanaan dari satu atau lebih aset yang akan dimiliki selama beberapa tahun kedepan yang diharapkan memberikan keuntungan bagi orang yang berinvestasi bisa juga disebut investor. Masyarakat kini memiliki wadah alternatif untuk berinvestasi yaitu di pasar modal.

Pasar modal merupakan salah satu indikator perekonomian suatu negara serta menunjang perkembangan ekonomi negara yang bersangkautan. Pasar modal muncul sebagai alternative pembiayaan eksternal bagi perusahaan, maka semakin banyak perusahaan yang akan go public dengan menjual saham perusahaan kepada masyarakat melalui pasar modal untuk mendapatkan dana segar tambahan dalam menjalankan perusahaannya.

Perusahaan dalam rangka memperoleh dana di pasar modal, ada beberapa cara yang bisa dilakukan. Salah satunya adalah dengan melakukan penjualan saham kepada masyarakat yang di kenal dengan istilah go public di Pasar Modal. Perusahaan yang telah go 
public ada waktunya membutuhkan dana segar kembali jika sumber internal serta pinjaman melalui bank dianggap kurang menguntungkan. Perusahaan dapat melakukan corporate action untuk mencari dana tambahan dengan cara menawar saham lagi kepada investor baik melalui penawaran umum maupun penawaran terbatas. Penawaran umum saham di tawarkan kepada investor secara keseluruhan, sedangkan penawaran terbatas saham ditawarkan kepada pemegang saham saat ini (existing shareholder) terlebih dahulu dengan harga tertentu dan dalam waktu tertentu yang biasanya lebih rendah dari harga pasar yang akhirnya menarik investor untuk membeli, penawaran terbatas ini biasanya disebut dengan right issue.

Right Issue di Indonesia lebih dikenal dengan Hak Memesan Terlebih Dahulu (HMTD). Bagi investor yang mengabaikan right issue akan mengalami dilusi terhadap kepemilikan saham. Sifatnya hak bukan kewajiban, maka ketika pemegang saham tidak ingin melaksanakan haknya maka dapat menjual hak tersebut dengan demikian terjadilah perdagangan terhadap right issue. Right issue diperdagangkan seperti halnya saham, namun ada masa berlakunya.

Right issue memiliki daya tarik sendiri kepada beberapa investor dikarenakan harga saham baru perusahaan yang ditawarkan perusahaan lebih murah dari harga saham perusahaannya yang sedang diperdagangkan pada pasar modal. Investor lama yang memiliki hak untuk membeli terlebih dahulu ini tentu mendapat kesempatan yang menguntungkan dikarenakan bisa membeli saham perusahaan lebih murah dari harga pasar dan mendapatkan keuntungan capital gain. Menurut Pakpahan (2010:10) : "Right issue memiliki tahapan pengumuman di mana diantaranya ada cum-date dan ex-date," bagi investor yang memiliki saham atau membeli saham pada masa cum-date dan sebelum cum-date dan tetap disimpan sahamnya sampai masa ex-date maka investor tersebut bisa mendapatkan hak right issue karena diperhitungkan sebagai investor lama sama karakteristiknya seperi pembagian dividen. Tranaksi sebelum penggumuman right issue ini tentu berbeda ketika sesudah pengumuman right issue dikarenakan para investor dapat membeli secepatnya saham perusahaan sebelum munculnya ketentuan pengumuman right issue sehingga hal ini menimbulkan suatu reaksi pasar yang fluktuatif sebelum pengumuman right issue dan juga sesudah pengumuman right issue.

Fenomena reaksi pasar biasanya juga terbentuk ketika adanya pengumuan perusahaan yang melakukan right issue. Artikel tempo.co Toyudho (17/04/17) dengan judul "Dikabarkan right issue, Saham BUMI Melonjak 6 Persen" membahas tentang bagai mana pergerkan saham PT Bumi Resources Tbk mengalami kenaikan setelah memberikan informasi rencana right issue. Artikel CNBC Indonesia dengan penulis Franedya (02/10/2018) juga membahas hal yang sama terjadi pada perusahaan PT Restia Bintang Mahkotasejati Tbk dengan judul artikel "Berencana Right issue, Harga Saham RBMS Naik 25\%". Berdasarkan kedua artikel di atas menunjukan suatu reaksi pasar yang terjadi ketika mendapat informasi adanya right issue bahkan pada kasus perusahaan PT Restia Bintang Mahkotasejati Tbk baru berencana melakukan right issue dengan belum adanya pengumuman kapan right issue dilakukan langsung mengalami kenaikan sebesar $25 \%$. 
Menurut Hartono, 2015:318 "Reaksi pasar berupa fluktuasi tersebut biasanya diukur menggunakan return sebagi nilai perubahan harga saham atau dapat juga menggunakan abnornal return" dan menggunakan likuiditas saham yang merupakan suatu indikator dari reaksi pasar terhadap suatu pengumuman yang diukur dengan Trading Volume Activity, Menurut Gunaasih dan Irfan (2015:108) : "Trading Volume Activity (TVA) merupakan instrument yang digunakan untuk mengamati serta mengukur reaksi pasar modal terhadap informasi atau peristiwa yang terjadi di pasar modal".

Setelah mengetahui bahwa right issue merupakan salah satu informasi yang dibutuhkan oleh investor untuk melakukan pembelian saham sehingga menimbulkan reaksi pasar yang fluktuatif, maka penelitian ini bertujuan untuk meneliti apakah right issue memiliki informasi yang cukup untuk membuat pergerakan harga pasar bereaksi terhadap pengumuman tersebut dengan membandingkan keadaan pasar sebelum dan sesudah pengumuman right issue. Penelitian terdahulu rata-rata menggunakan sampel semua emiten yang melakukan right issue seperti Jayanti (2014:7), Dewi (2013:163) dan Ariani (2014:52) sehingga peneliti mendapat gap riset untuk melakukan penelitian berdasarkan sektor dengan memilih perusahaan-perusahaan sektor infrastruktur di Bursa Efek Indonesia (BEI) pada tahun 2015-2018.

Berdasarkan latar belakang tersebut maka peneliti ingin menulis penelitian dengan judul "Analisis Reaksi Pasar Bursa Efek Indonesia Sebelum dan Sesudah Pengumuman Right Issue Terhadap Abnormal Return dan Likuiditas Saham (Studi Kasus pada Perusahaan-Perusahaan yang Terdaftar di Bursa Eefek

\section{Indonesia Tahun 2015-2018 Sektor Infrastruktur) "}

\section{Rumusan Masalah}

Berdasarkan latar belakang yang telah dikemukakan sebelumnya, permasalahan pada usulan penelitian ini dapat dirumuskan sebagai berikut :

1. Apakah terdapat perbedaan abnormal return saham sebelum dan sesudah pengumuman right issue pada perusahaan-perusahaan sektor infrastruktur di Bursa Efek Indonesia tahun 2015-2018?

2. Apakah terdapat perbedaan Likuiditas saham sebelum dan sesudah pengumuman right issue pada perusahaan-perusahaan sektor infrastruktur di Bursa Efek Indonesia tahun 2015-2018?

\section{Tujuan Penelitian}

Penelitian ini mempunyai tujuan untuk menguji efisiensi pasar di Bursa Efek Indonesia dilihat dari reaksi harga saham dengan right issue. Secara lebih khusus tujuan penelitian ini adalah:

a. Menganalisa perbedaan Abnormal return saham sebelum dan sesudah pengumuman right issue pada perusahaan-perusahaan sektor infrastruktur di Bursa Efek Indonesia tahun 2015-2018

b. Menganalisa perbedaan Likuiditas saham sebelum dan sesudah pengumuman right issue pada perusahaan-perusahaan sektor infrastruktur di Bursa Efek Indonesia tahun 2015-2018

\section{Pasar Modal}

Pasar modal pada dasarnya tempat prasarana antara pihak yang membutuhkan dana dan pihak pemasok dana (supplier of found). Menurut Undang-Undang No.8 Tahun 1995 tentang Pasar Modal adalah : "Pasar modal yaitu sebagai suatu kegiatan yang bersangkutan dengan penawaran umum 
dan perdagangan efek, perusahaan publik yang berkaitan dengan efek yang diterbitkannya, serta lembaga dan profesi yang berkaitan dengan efek."

\section{Corporate action}

Menurut Situmorang, (2010:145)

: "Corporate action adalah tindakan atau aksi korporasi emiten (perusahaan go public) yang berpengaruh terhadap harga saham peusahaan yang bersangktan di bursa." Berita Corporate action umumnya menarik perhatian pihakpihak yang terkait di pasar modal, khususnya para pemegang saham.

\section{Right Issue}

Pasar modal (capital market) Indonesia memiliki ketentuan penerbitan right issue diatur pada Keputusan Ketua Bapepam Nomor: Kep-41/ PM/2003 tangal 17 Juli 2003 Peraturan Nomor IX. D. 1: Hak Memesan Efek Terlebih Dahulu (right issue). Pasar modal Indonesia lebih mengnal right issue dengan istilah Hak Memesan Efek Terlebih Dahulu (HMETD) dari ketentuan hukum yang mengatur adanya preventive right ada di setiap pemegang saham lama dalam perseroan terbatas, dimana setiap pemegang saham yang terdaftar di dalam daftar pemegang saham, ia berhak untuk mendapatkan hak untuk membeli setiap saham baru atau yang dikeluarkan di dalam portofolio perseroan.

\section{Abnormal Return}

Menurut Tandelilin (2010: 571) : "Abnormal return merupakan selisih (positif atau negatif) dari return aktual di seputar pengumuman $\left(\mathrm{R}_{\mathrm{i}}\right)$ dengan return ekspektasi $\left(\mathrm{R}_{\mathrm{mt}}\right)$ ".

\section{Likuiditas Saham}

Mulyana (2011:99) mengatakan "likuiditas saham merupakan ukuran jumlah transaksi suatu saham di pasar modal dalam suatu periode tertentu, jadi semakin likuid saham maka frekuensi transaksi semakin tinggi”.

Aktivitas volume perdagangan selalu berubah-ubah tiap waktu setiap adanya suatu informasi tentang perusahan, mengitung seberapa reaksi volume terhadap informasi yang mempengaruhi likuiditas saham maka digunakan Trading Volume Activity (TVA). Trading Volume Aactivity dapat mengukur seberapa besar suatu informasi atau peristiwa menimbulkan reaksi pasar, Napitupulu dan Syahunan (2014:14), mengatakan: "Trading Volume Activity (TVA) merupakan suatu indikator yang dapat digunakan untuk melihat reaksi pasar modal terhadap informasi yang beredar di pasar modal dengan menggunakan aktivitas volume perdagangan saham sebagai parameternya."

\section{METODE PENELITIAN}

\section{Jangkauan Penelitan}

Jangkauan penelitian ini menggunakan periode pengamatan 21 hari dimana 10 hari sebelum dan 10 hari sesudah dan 1 hari periode pengumuman untuk menghitung reaksi pasar menggunakan abnormal return dan trading volume activity. Priode penelitian yang diambil adalah 4 tahun (2015-2018) dan peneliti melakukan penelitian pada tahun 2019 .

\section{Teknik Pengumpulan Data}

Teknik pengumpulan data pada penelitian ini adalah penelitian kepustakaan (library research), yaitu penelitian yang digunakan oleh peneliti dengan mengumpulkan dasar teori dari buku-buku referensi, jurnal dan artikel.

\section{Populasi dan Sampel}

Populasi dalam penelitian ini adalah perusahaan sektor Infrastrukturdi Bursa Efek Indonesia pada tahun 2015- 
2018 yang berjumlah 72 perusahaan. Penentuan sampel ini menggunakan purposive sampling berdasarkan kriteria yang ditentukan peneliti terdapat 6 perusahaan Infrastruktur yang mengumumkan right issue pada periode tersebut.

Tabel 1 Sampel

\begin{tabular}{|c|c|l|}
\hline NO & $\begin{array}{c}\text { Kode } \\
\text { Saham }\end{array}$ & \multicolumn{1}{|c|}{ Nama Perusahan } \\
\hline 1 & EXCL & PT XL Axiata Tbk \\
\hline 2 & JSMR & PT Jasa Marga Tbk \\
\hline 3 & CENT & $\begin{array}{l}\text { PT Centratama } \\
\text { Telekomunikasi Indonesia Tbk }\end{array}$ \\
\hline 4 & LEAD & $\begin{array}{l}\text { PT Logindo Samudramakmur } \\
\text { Tbk }\end{array}$ \\
\hline 5 & CMPP & PT Indonesia AirAsia Tbk \\
\hline 6 & FREN & PT Smartfren Telecom Tbk \\
\hline
\end{tabular}

Sumber : idx.co.id (2019)

\section{Alat Analisis}

Ada beberapa alat analisis yang digunakan dalam penelitian ini serta langkah yang dilakukan oleh peneliti dalam penelitian ini, yaitu:

\section{Mengolah Data}

a. Abnormal Return

$$
\square_{\square \square}=\square_{\square \square}-\square_{\square \square}
$$

Sumber: Hartono (2015:648)

Keterangan:

$$
\begin{aligned}
& \square \square_{\square \square}=\text { abnormal return sekuritas i pada } \\
& \square_{\square \square}=\text { actual return pada periode } t \\
& \square \square \square=\text { expected return pada } \\
& \text { periode } t
\end{aligned}
$$

\section{b. Trading Volume Activity (TVA)}

$$
\square \square \square=\frac{\sum \text { saham } \square \text { ditransaksikan pada waktu } \square}{\sum \text { saham } \square \text { yang beredar pada waktu }}
$$

Sumber: Waisnawa (2015:3)

Keterangan:

$$
\begin{array}{ll}
\sum_{t} & =\text { jumlah } \\
& =\text { periode waktu yang ingin } \\
& \text { dihitung } \\
i & =\text { perusahhaan }
\end{array}
$$

\section{Uji Statistik}

Data yang telah dihitung kemudian dihitung kembali dalam perhitungan statistik, dalam penelitian ini perhitugan statistik menggunakan aplikasi SPSS

a. Statistik Deskriptif

Penelitian ini merupakan studi empiris (emperical study) dimana studi tentang fakta atau data yang nyata yang dikumpulkan dan diuji secara sistematis. Menurut Sugiyono (2014:207): "Metode statistik deskriptif adalah statistik yang digunakan untuk menganalisis data dengan cara mendeskripsikan atau menggambarkan data yang telah terkumpul sebagaimana adanya tanpa bermaksud membuat kesimpulan yang berlaku untuk umum atau generalisasi." b. Uji Normalitas

Menurut Paramesti (2014:24): "Uji normalitas data menghasilkan data yang berdistribusi normal, maka alat analisa yang digunakan adalah uji statistik parametrik, yaitu pengujian dua sampel berpasangan (paired sample $t$ test), data tidak berdistribusi normal, maka alat analisa yang digunakan adalah uji statistik non parametrik Wilcoxon Signed Rank Test."

\section{c. Paired Sample t-Test}

Model uji beda ini digunakan untuk menganalisis model penelitian pre-post atau sebelum dan sesudah. Menurut Pramana, (2012:41): "Uji beda digunakan untuk mengevaluasi perlakuan (treatment) tertentu pada satu sampel yang sama pada dua periode pengamatan yang berbeda". Paired sample t-test digunakan apabila data berdistribusi normal.

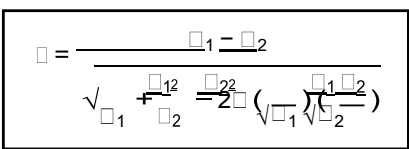

Sumber : Gani (2018:63)

Keterangan 


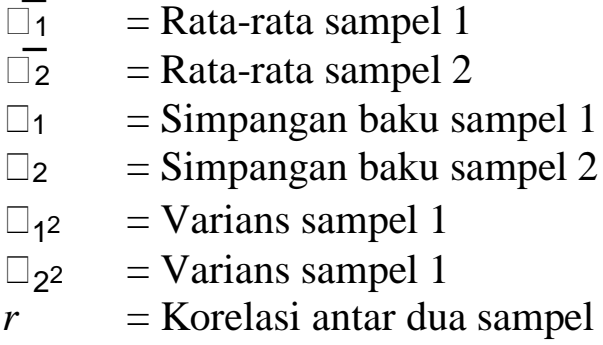

\section{Pengujian Hipotesis}

Penelitian ini pengujian hipotesis dilakukan dengan menetapkan taraf signifikansi (confident interval). Taraf signifikansi yang ditetapkan adalah sebesar 5\% $(\alpha=0,05)$.

\section{Hipotesis diterima}

$\mathrm{Ha}_{1} \quad$ Terdapat perbedaan Abnormal return sebelum dan sesudah pengumuman right Issue pada perusahaan-perusahaan infrastruktur yang terdaftar di Bursa Efek Indonesia periode 2015-2018

$\mathrm{Ha}_{2} \quad$ Terdapat perbedaan Likuiditas saham sebelum dan sesudah pengumuman right Issue pada perusahaan-perusahaan infrastruktur yang terdaftar di Bursa Efek Indonesia periode 2015-2018

\section{Hipotesis ditolak}

$\mathrm{Ho}_{1}$ Tidak terdapat perbedaan Abnormal return sebelum dan sesudah pengumuman right Issue pada perusahaan-perusahaan infrastruktur yang terdaftar di Bursa Efek Indonesia periode 2015-2018

$\mathrm{Ho}_{2}$ Tidak terdapat perbedaan Likuiditas saham sebelum dan sesudah pengumuman right Issue pada perusahaan-perusahaan infrastruktur yang terdaftar di Bursa Efek Indonesia periode 2015-2018

Keputusan statistik :

1. Jika $t_{\text {hitung }}>\mathrm{t}_{\text {tabel }}$ atau Probabilitas $<$ 0,05, maka Ho ditolak dan $\mathrm{Ha}$ diterima

2. Jika $t_{\text {hitung }}<\mathrm{t}_{\text {tabel }}$ atau Probabilitas $>$ 0,05, maka Ho diterima dan $\mathrm{Ha}$ Ditolak

\section{HASIL DAN PEMBAHASAN}

\section{Analisis}

Berikut merupakan gambar grafik dari rata-rata Abnormal Return sebelum dan sesudah pengumuman right issue dalam periode pengamatan 10 hari sebelum dan 10 hari sesudah :

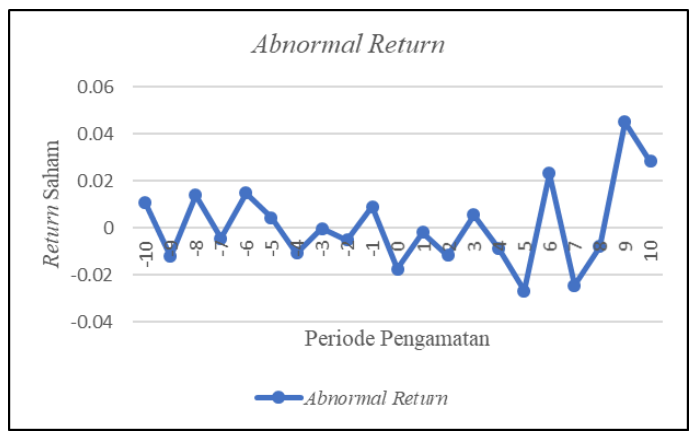

Sumber : diolah peneliti (2019)

Gambar 1 Grafik rata-rata Abnormal return

Keterangan : -10 sampai -1 adalah periode sebelum pengumuman right issue

0 adalah periode pengumuman right issue

1 sampai dengan 10 adalah periode sesudah pengumuman right issue

Terlihat dari gambar 1 bahwa pergerakan abnormal return fluktuatif selalu berubah-ubah selama periode penelitian, merupakan hal yang wajar jika return mengalami fluktuatif, namun yang ingin kita lihat nanti adalah apakah signifikan atau tidaknya perubahan abnormal return sebelum dan sesudah pengumuman right issue.

Berikut merupakan gambar grafik dari rata-rata trading volume activity sebelum dan sesudah pengumuman right issue dalam periode pengamatan 10 hari sebelum dan 10 hari sesudah : 


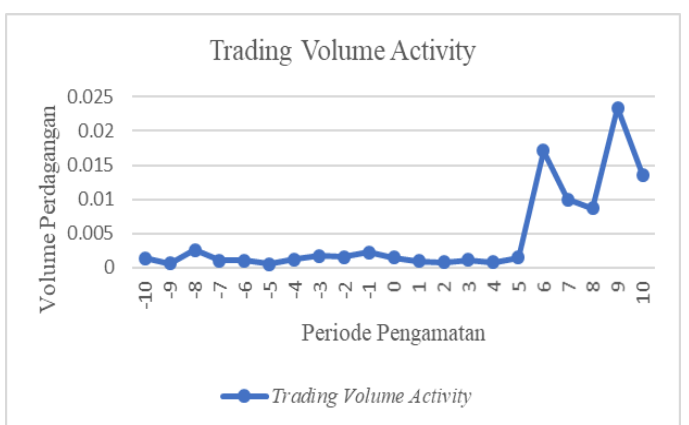

Sumber : diolah peneliti (2019)

Gambar 2 Grafik rata-rata trading volume activity

Keterangan : -10 sampai -1 adalah periode sebelum pengumuman right issue

0 adalah periode pengumuman right issue

1 sampai dengan 10 adalah periode sesudah pengumuman right issue

Terlihat dari gambar 2 bahwa pergrakan trading volume activity fluktuatif seslalu berubah-ubah selama periode penelitian, merupakan hal yang wajar jika return mengalami fluktuatif bahkan pada periode setelah pengumuman mengalami kenaikan yang tinggi, namun yang ingin kita lihat nanti adalah apakah signifikan atau tidaknya perubahan trading volume activity sebelum dan sesudah pengumuman right issue.

\section{Deskriptif Statistik}

Penelitian ini menggunakan model sesuai-rata-rata (mean-adjusted model) dalam menghitung abnormal return. Penelitian ini menggunakan hasil dari perhitungan Cummulative Average Abnormal Return (CAAR) dan Average Trading Volume Activity (XTVA). Tujuannya untuk mengetahui perbedaan abnormal return dan trading volume activity sebelum dan sesudah pengumuman right issue ( $\mathrm{t}-10$ hingga $\mathrm{t}-$ 1) dan sesudah pengumuman ( $t+1$ hingga $\mathrm{t}+10)$.
Tabel 2 Desciptive Statistic

Descriptive Statistics

\begin{tabular}{|l|r|c|c|c|c|}
\hline & \multicolumn{1}{|c|}{$\mathrm{N}$} & Minimum & Maximum & Mean & Std. Deviation \\
\hline AR Sebelum & 10 & .012103 & .014851 & .00204560 & .009994980 \\
AR Sesudah & 10 & .026676 & .045286 & .00211577 & .023508723 \\
TVA Sebelum & 10 & .000566 & .002609 & .00140042 & .000652307 \\
TVA Sesudah & 10 & .000774 & .023432 & .00778902 & .008166687 \\
Valid N (listwise) & 10 & & & & \\
\hline
\end{tabular}

sumber : diolah peneliti (2019)

Berdasarkan tabel 2 hasil minimum abnormal return sebelum 0.012103 dimiliki oleh periode sebelum pengumuman hari ke (-9) dan maxsimum abnormal return sebelum 0.014851 dimiliki oleh perode sebelum pengumuman hari ke (-6). Minimum abnormal return sesudah -0.026676 dimiliki oleh periode sesudah pengumuman hari ke 5 dan maxsimum abnormal return sesudah 0.045286 dimiliki oleh periode sesudah pengumuman hari ke 9. Minimum trading volume activity sebelum memiliki nilai 0.000566 dimiliki oleh periode sebelum pengumuman hari ke (5) dan maxsimum trading volume activity sebelum 0.002609 dimiliki oleh perode sebelum pengumuman hari ke(8). Minimum trading volume activity sesudah 0.000774 dimiliki oleh periode sesudah pengumuman hari ke 4 dan maksimum trading volume activity sesudah 0.023432 dimiliki oleh perode sesudah pengumuman hari ke 9 .

\section{Uji Normalitas}

Pengujian normalitas pada penelitian ini menggunakan Kolmogronov-Smirnov, dengan taraf signifikansi yang ditetapkan adalah sebesar 5\% $(\alpha=0,05)$ dengan hipotesis statistik uji normalitas sebagai berikut :

Ho = Data tidak berdistribusi normal

$\mathrm{Ha}=$ Data berdistribusi normal

Keputusan : 
1. Asymp. Sig.(output SPSS) > 0.05, maka data terdistribusi secara normal

2. Asymp. Sig. (output SPSS) < 0.05, maka data tidak terdistribusi secara normal

Berikut merupakan hasil uji normalitas untuk abnormal return dan trading volume activity :

Tabel 3 One Sample KolmogronovSmirnov Test

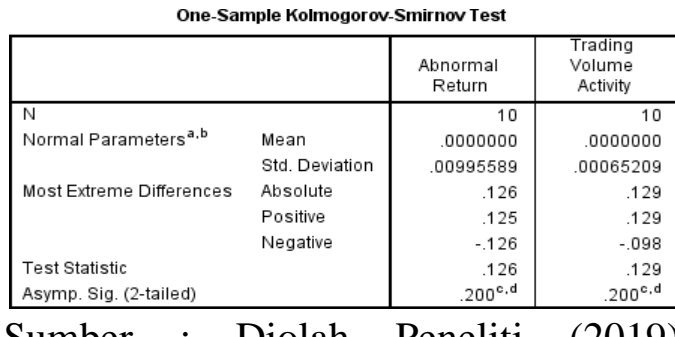

Berdasarkan hasil dari One Sample Kolmogronov-Smirnov Test pada tabel 3 hasil dari uji normalitas Kolmogronov-Smirnov ini menghasilkan
Asymptotic Significance untuk abnormal return diatas 0,05 dan trading volume activity di atas 0,05 hasil ini menunjukan data berdistribusi normal maka Ho ditolak dan $\mathrm{Ha}$ diterima. Ha diterima maka uji beda dapat dilakukan dengan paired sample t-test.

\section{Paired Sample T-Test}

Uji Paired Sample T-Test digunakan untuk menganalisis ada tidaknya perbedaan secara signifikan antara abnormal return sebelum dan sesudah pengumuman right issue dan menganalisis ada tidaknya perbedaan secara signifikan antara likuiditas saham sebelum dan sesudah pengumuman right issue. Pengujian dilakukan dengan tingkat signifikansi 5\% atau 0,05. Berikut merupakan hasil paired sample t-test dari abnormal return dan trading volume activity :

Tabel 4 Paired Sample T-Test

\begin{tabular}{|c|c|c|c|c|c|c|c|c|c|}
\hline \multicolumn{10}{|c|}{ Paired Samples Test } \\
\hline & & \multicolumn{5}{|c|}{ Paired Differences } & \multirow[b]{3}{*}{$t$} & \multirow[b]{3}{*}{ df } & \multirow[b]{3}{*}{ Sig. (2-tailed) } \\
\hline & & \multirow[b]{2}{*}{ Mean } & \multirow[b]{2}{*}{ Std. Deviation } & \multirow{2}{*}{$\begin{array}{l}\text { Std. Error } \\
\text { Mean }\end{array}$} & \multicolumn{2}{|c|}{$\begin{array}{l}\text { 95\% Confidence Interval of the } \\
\text { Difference }\end{array}$} & & & \\
\hline & & & & & Lower & Upper & & & \\
\hline & $\begin{array}{l}\text { AR Sebelum - AR } \\
\text { Sesudah }\end{array}$ & -.000070176 & .024719212 & .007816901 & -.017753235 & .017612883 & -.009 & 9 & .993 \\
\hline Pair 2 & $\begin{array}{l}\text { TVA Sebelum - TVA } \\
\text { Sesudah }\end{array}$ & -.006388604 & .008175860 & .002585434 & -.012237262 & -.000539947 & -2.471 & 9 & .036 \\
\hline
\end{tabular}

Sumber : Diolah Peneliti (2019)

Berdasarkan hasil uji dari paired sample t-test, abnormal return sebelum dan sesudah pengumuman right issue menghasilkan thitung sebesar $-0,009$ dan $t_{\text {tabel }}-2,262$ dengan nilai Probabilitas sebesar 0,993 dimana $t_{\text {hitung }}<\mathrm{t}_{\text {tabel }}$ atau Probabilitas $>0,05$ sehingga $\mathrm{Ha}_{1}$ ditolak dan $\mathrm{Ho}_{1}$ diterima. Trading volume activity sebelum dan sesudah pengumuman right issue menghasilkan $t_{\text {hitung }}$ sebesar $-2,471$ dan $t_{\text {tabel }}-2,262$ dengan nilai Probabilitas sebesar 0,036 dimana $t_{\text {hitung }}>\mathrm{t}_{\text {tabel }}$ atau Probabilitas < 0,05 sehingga $\mathrm{Ho}_{2}$ ditolak dan $\mathrm{Ha}_{2}$ diterima.

\section{KESIMPULAN DAN SARAN}

\section{Kesimpulan}

Analisis hasil penelitian yang telah dikemukakan pada bab sebelumnya, maka kesimpulan penelitian ini adalah sebagai berikut :

1. Pengumuman right issue tidak berpengaruh signifikan terhadap abnormal return pada periode sebelum dan sesudah pada perusahaan-perusahan infrastruktur yang terdaftar di Bursa Efek Indonesia periode 2015-2018. 
2. Pengumuman right issue berpengaruh signifikan terhadap likuiditas saham pada periode sebelum dan sesudah pada perusahaan-perusahan infrastruktur yang terdaftar di Bursa Efek

Indonesia periode 2015-2018

\section{Saran}

Berdasarkan analisis dari hasil penelitian yang telah dilakukan, saran yang dapat diberikan adalah sebagai berikut :

1. Saran bagi emiten apabila perusahaan menginginkan keuntungan sebaiknya bisa melakukan corporate action yang lain seperti saham bonus, stock split atau dividen karena pada pengumuman right issue tidak terdapat perbedaan pada abnormal return dan likuiditas saham.

2. Memperbaiki kinerja perusahaan agar meningkatkan harga saham merupakan hal yang dinilai lebih baik secara fundamental dan dapat menghasilkan keuntungan dimasa depan.

3. Saran bagi investor pengumuman right issue tidak memberikan anormal return dan likuiditas saham yang signifikan. Investor harus lebih memerhatikan informasi mengenai pengumuman right issue serta melihat kondisi perusahaan secara fundamental dan teknikal.

4. Bagi peneliti selanjutnya bisa mengunakan Market Adjusted Model dalam menghitung abnormal return.

5. Menambah variabel analisis teknikal dalam penelitian seperti moving Average, pipot table dan lainnya sehingga penelitian lebih variatif mengingat investor juga memperhitungkan trend dalam membeli saham.

\section{REFERENCES}

Anonim. 1995. Undang-Undang No.8 Tahun 1995 tentang Pasar Modal. www.ojk.go.id. Diakses pada hari Kamis, 28 Maret 2018

- 2003. Keputusan Ketua Bapepam Nomor: Kep-41/ PM/2003 Nomor IX. D.1 tentang Hak Memesan Efek Terlebih Dahulu. www.ojk.co.id. Diakses pada hari Kamis, 28 Maret 2018

Basuki, Agus Tri. 2015. Analisis Satistik Dengan SPSS. Yogyakarta : Danisa Media.

Fahmi, Irham. 2013. Analisia Laporan Keuangan. Bandung : Alfabeta

Franedeya, Roy. 2018. "Berencana Rights Issue, Harga Saham RBMS Naik 25\%". CNBC Indonesia. https://www.cnbcindonesia.com/ market/20181002101914-1735629/berencana-rights-issueharga-saham-rbms-naik-25. Diakses pada hari Minggu, 31 Maret 2019

Gani, Irwan dan Siti Amalia. 2018. Alat Analisis Data Edisi Revisi. Yogyakarta : Andi Publiser

Gunaasih, dan Nursasmito, Irfan. 2015. The Evaluation of NonEconomic Event Towards the LQ-45 Index in Indonesia Stock Exchange by Using Event Study Method, Integrative Busines \& Economic Research, Vol. 4, No. 2. ISSN: 2304-1013. www.sibresearch.org. Diakses pada hari Kamis, 28 Maret 2018 
Hartono, Jogiyanto. 2015. Teori Portofolio dan Analisis Investasi. Yogyakarta : BPPEE

Mulyana, Deden. (2011). Analisis Likuiditas Saham Serta Pengaruhnya Terhadap Harga Saham Pada Perusahaan Yang Berada Pada Indeks LQ45 di Bursa Efek Indonesia. Jurnal Magister Manajemen Volume 4 Nomor 1 Maret 2011. unsil.ac.id. Diakses pada hari Jumat, 29 Maret 2019

Napitupulu, Veronica dan Syahyunan. 2013. Pengaruh Return Saham, Volume Perdagangan Saham dan Volatilitas Harga Saham terhadap Bid-ask Spread pada Perusahaan yang Melakukan Stock Split di Bursa Efek Indonesia. Jurnal Media Informasi Manajemen, Vol. 1 No 2. jurnal.usu.co.id. Diakses pada hari Jumat, 29 Maret 2019

Pakpahan, Mora Asriadi. 2014. Analisa Pengaruh Pengumuman Right Issue Terhadap Capital Gain Dan Trading Volume Activity Pada Perusahaan Non Manufaktur Di Bursa Efek Jakarta. repository.usu.ac.id. Diakses pada hari Sabtu, 30 Maret 2019

Paramesti, Getut. 2014. Kupas Tuntas Data Penelitian dengan SPSS 22. Jakarta : PT. Elex Media Komputindo.

Pramana, Andi. 2012. Analisis Perbandingan Trading Volume Activity dan Abnormal Return Saham Sebelum dan Sesudah Pemecahan Saham (Studi Kasus Pada Perusahaan Yang
Terdaftar di Bursa Efek Indonesia Periode 20072011).Universitas Diponegoro, Semarang. http://eprints.undip.ac.id. Diakses pada hari Jumat, 29 Maret 2019

Sarwono, Jonathan. 2009. Analisis Data Penelitian Menggunakan SPSS. Yogyakarta : Andi Publiser

Situmorang, M Paulus. 2010. Pengantar Pasar Modal. Jakarta : Mitra Wacana Media.

Sugiyono. 2012. Metode Penelitian Bisnis (Pendekatan Kuantitatif, Kualitatif, dan R\&D). Bandung : Alfabeta.

Tampubolon, M.P. 2013. Manajemen Keuangan. Bogor : Gualia.

Tandelilin, Eduardus. 2010. Portofolio dan Investasi Teori dan Aplikasi (Edisi Pertama). Yogyakarta: Kanisius.

Toyudho , Eko Siswono. 2017. "Dikabarkan Right Issue, Saham BUMI Melonjak 6 Persen”.

Tempo.co https://bisnis.tempo.co/read/866 684/dikabarkan-right-issuesaham-bumi-melonjak-6persen/full\&view=ok. Diakses pada hari Minggu, 31 Maret 2019

Waisnawa, I Putu Gede Brahmaputra. 2015. Analisis Reaksi Pasar Atas Pengumuman Stock Split Oleh PT. JAPFA COMFEED INDONESIA Tbk Tahun 2013. Jurnal Administrasi Bisnis Vol. 23 No.1 Juni 2015. Diakses pada hari Minggu, 31 Maret 2019 